\title{
Examining Selected Business Factors Determining Access to Black Business Supplier Development Programme Funding in South Africa
}

\author{
Timothy Olaniyi Aluko ${ }^{1}$ and Paul Kibuuka ${ }^{2}$
}

\begin{abstract}
This paper examines selected business factors determining access to Black Business Supplier Development Programme (BBSDP) funding in South Africa over the financial period 2011/12 to 2014/15. Raw data was sourced from the BBSDP database. Approved amount (AM) was the dependent variable while turnover amount prior to application (TA), number of employees in the previous year (NE), and distinct amounts required for tools and machinery (TM), business development (BD), and training (TR) were used as covariates in the model. Weighted estimation regression through the origin in Statistical Package for the Social Sciences (SPSS) statistical program was applied for statistical analysis. Estimated results indicate that turnover prior to application, and the distinct amounts required for tools and machinery, business development, and training purposes, all had statistically significant positive effects on the amounts approved for firms during the period under review. In conclusion, the paper recommends that Small and Medium Enterprises (SMEs) need to focus on investing in tools and machineryand business development as well as increasing their turnover levels in order to improveaccess to government funding.
\end{abstract}

Key words:- BBSDP, SMEs, Service Sector, Manufacturing Sector, and South Africa

\section{INTRODUCTION AND BACKGROUND}

The importance of small and medium enterprises (SMEs) in South Africais witnessed in terms of the contribution towardsthe gross domestic product (GDP) and employment creation across numerous sectors of the economy. Although SMEs contribute as little as 25 percent to capital formation compared to large enterprises, it is noticeable that they have a major socioeconomic role to play in the country. It was estimated by the Task Group of the Policy Board for Financial Services and Regulation that, the contribution of SMEs to GDP in South Africa stands at more than 50 percent, while the contribution to employment stands at more than 60 percent (Falkena, Abedian, Blottnitz, Coovadia, Davel, Madungandaba, Masilela, \&Rees, 2013:13). Though there are many sectors that contribute to the economy's growth, this study focuses particularly on access to the BBSDP funding by SMEs in the services sector (non-financial) and manufacturing sector. With the annual GDP growth rate standingat 1.3 percent in 2015, the contributions by the services sector (19.6 percent) and manufacturing sector (12.6 percent) to the real GDP (Statistics South Africa, 2016) demonstrate the importance of the respective sectors in the economy. The services sector firms covered in this study are those that fall in the categories of non-financial business servicessuch as, security firm, computer services, legal services, accounting and bookkeepingand real estate firm.

In South Africa, SMEs are defined with reference to the number of employees or to the turnover bands or a combination of both, as prescribed in the National Small Business Act, 1996. Section 1 of National Small Business Act of 1996, as amended by the National Small Business Amendment Acts of 2003 and 2004 , officiallydefines a small business as "a separate and distinct business entity, including co-operative enterprises and nongovernmental organisations, managed by one owner or more, which, including its branches or subsidiaries, if any, is predominantly carried on in any sector or sub-sector of the economy mentioned in Column I of the Schedule". The small businesses are further categorised by the Act into distinct groups, namely survivalist, micro, very small, small, and medium. According to the Act, a small enterprise is one that has fewer than 50 employees, anannual turnover of less than R2 million to R25 million, and gross assets (excluding fixed property) less than R2 million to R4.5 million, depending on the industry. Moreover, a medium enterprise is one that has fewer than

${ }^{1} \mathrm{PhD}$ (Development Finance) Candidate at University of Stellenbosch Business School, Cape Town. South Africa

${ }^{2}$ Professor at University of South Africa (UNISA).

Corresponding email address: toa@timnet.co.za; kibuup@unisa.ac.za

Postal address: P.O.BOX 27014, Sunnyside, 0132 Pretoria.

DOI: $10.9790 / 0837-2109043644$

www.iosrjournals.org

36 | Page 
100 to 200 employees, an annual turnover of less than R4 million to R5 million and gross assets (excluding fixed property) of less than R2 million and R18 million, depending on industry (NCR, 2011).

Against the backdrop of stagnation in turnover and employment growth experienced by SMEs in the country, the Black Business Supplier Development Programme (BBSDP) was introduced by the Department of Trade and Industry under the auspices of the World Bank during 2002. Currently under administration by the Department of Small Business Development (DSBD) since 2014, the BBSDP was implemented to address the constraints faced by black-owned SMEs and at the same time, broadening the activities eligible for assistance and increasing the level of funding support. The BBSDP (2010) defines a black enterprise as "a business owned by at least 51 percent of South African black people".It goes further to definethe supplier enterprise as "an individual or enterprise that renders a service (in terms of the approved interventions and/or activities to an approved BBSDP beneficiary) and ensures that the successful claim of an approved intervention is submitted". According to the Department of Small Business Development (DSBD, 2010), the BBSDP is a cost-sharing grant offered to black-owned small enterprises with the aim to assist such enterprises in improving their competitiveness and sustainability, and ensuring integration into the main economy. The grants are provided up to a maximum value of R800 000 for tools, machinery, and equipment, and R200 000 for business development and training interventions per eligible enterprise. The major goal of such grants is to improve corporate governance, marketing, management, productivity, and use of modern technology. Through the multiplier effect, the programme's outcomes are to improve sustainability of black-owned enterprises and increasing employment. In order to be eligible for the grants, the enterprise should be predominantly black-owned by at least 51 percent of black South African citizens, have a predominantly black management team (50 percent), have an annual turnover of R250 000 thousandto R35 million, be registered with the South African Revenue Service (SARS) for VAT if applicable, and be able to provide a valid tax clearance certificate and VAT registration number, and have been operating and trading as a registered and tax-complaint enterprise for a period of at least one financial year.

\subsection{Problem statement}

The value of SMEs remains highly recognised in many economies global-wide, irrespective of the economy's developmental stage. Their contribution towards economic growth and job creation remains an essential ingredient for socioeconomic development. Anchored on the perspective that small business is big business in South Africa, lack of access to finance remains the critical challenge for many SMEs in the economy (Kumah \& Omilola, 2014; Mago \& Toro 2013; Xiang \&Worthington, 2013; Ferreira, Strydom, \& Nieuwenhuizen, 2010). Despite all the initiatives made to stimulate SMEs' growth and sustainability during the post-apartheid epoch, Kumah andOmilola (2014) indicate that the growth of SMEs remains obstinately anaemic. Access to government financing remained a significant challenge for most SMEs in the economy.

\subsection{Research objective}

In light of the problem statement indicated above, the objective of this research study was to examine selected business factors determining access to BBSDP funding over the financial period 2011/12 to 2014/15.

1.3 Research question

What are the impacts of selected business factors determining access to BBSDP funding over the financial period 2011/12 to $2014 / 15$ ?

\section{LITERATURE REVIEW}

The role of SMEs in the socioeconomic growth and development of a nation cannot be overemphasized. With the objective of analysing alternative models of SME financing, Akorsu andAgyapong (2012) found that inappropriate risk management, moral hazard, and possible adverse selection were the factors that limited SMEs' access to financing from both the private sector and government. Abdulsaleh andWorthington (2013) reported that the financial behaviour and practices of SMEs are a significant factor that determines SMEs' access to funding sustainable growth and development in the respective sectors they operate. Most SMEs in developing countries have very limited access to deposits, credit facilities, and other financial services provided by both the government and formal private financial institutions (Mazanai \& Fatoki, 2011; Mago \& Toro, 2013). In the study towards establishing an alternative model for financing SMEs in Ghana, against the background of lenders being cynical in advancing credit to SMEs, Akorsu (2012) found that inappropriate risk, potential adverse selection, and moral hazard limit SMEs' access to credit. In that respect, Akorsu (2012) reported that the development of a SME Network Fund could be a lucrative alternative for a selfmanaged fund to finance with minimum requirements such as collateral security. The fund can technically comprise of private investors, state contributions such as venture capital funds and international donors.

In emphasising the importance of access to financing for SMEs'sustainable growth, innovation, facilitation of new business creation, and profitability, Abdulsaleh andWorthington (2013) undertook some literature survey to explore the influence of the financial behaviours of SMEs' owners or managers to different financing sources. 
The respective study reported that the industrial sector within which SMEs operate has significant influence on access to financing, and further explains the capital structure and financial decisions. In that respect, Abdulsaleh andWorthington (2013) found that firms in the services sector differ from firms operating in manufacturing or construction in terms of financial needs, decisions, and probabilities of access to financing. A previous, similar study by Michaelas, Chittenden,and Poutziouris (1999) analysed determinants of the capital structures across time and industrial sectors using a sample of three thousand five hundred $(n=3500)$ randomly selected SMEs across ten industrial sectors in the United Kingdom. The study found that industrial sectors, as well as the asset structures and capital requirements, influence SMEs' access to financing.

Similarly, Abor (2007) found that industrial sector classification has a significant influence on the capital structure, funding preferences, and access to funding by Ghanaian SMEs across industries. For instance, the study found that SMEs in the agricultural sector have relatively easy access to funding and they rely more on short-term debt than counterpart firms do in the manufacturing sectors that rely more on long-term financing with limited access to funding. Using the binary logistic regression approach, Le (2012) assessed the influence of firm and financial characteristics in terms of credit worthiness and industrial sector classification in the access to financing and probability of SMEs in Vietnam. The study found and confirmed that industrial sector classification had asignificant influence on SMEs' access to funding relative to creditworthiness. Technically, the odds to access to funding for firms operating in the manufacturing sector were higher than the odds of firms operating in the services sector. In examining the influence of access to credit on growth of SMEs in Ho Municipality of Volta Region in Ghana, Ahiawodzi andAdade (2012) surveyed a sample of seventy eight $(n=$ 78 ) in the manufacturing sector. Results from the econometric estimation revealed that the annual turnover of SMEs in the manufacturing sector havea significant effect on access to funding.

\subsection{Data preparation}

\section{METHODOLOGY AND ESTIMATION TECHNIQUE}

The raw data extracted from the Black Business Supplier Development Programme (BBSDP) database was sorted in MS Excel file. The approved amount values were subtracted from the application totalvalues to determine the difference between theappliedand the approvedvalues. For cases whereapproved amounts exceeded application amounts, negative differences were found,indicating unrealistic values. The "IF" logic function was used to assign binary codes 0 and 1 to realistic and unrealistic values respectively. From the sample of 833 cases, seven of them were detected unrealistic and eliminated from the dataset for analysis,leaving 826 valid cases. The approved amounts were divided by the application valuesto derive the percentages of approved amounts, which were further assigned binary codes for which 0 represents less than 50 percent approved amounts and 1 denoted equal to or greater than 50 percent approved amounts.

\subsection{Statistical analysis}

The SPSS version 21 for windows was used to perform statistical analysis. Cross-tabulation based frequencies, descriptive statistics, and weighted least squares linear regression through the origin, were conducted in the analysis.

\subsubsection{Descriptive statistics}

Descriptive statistics, which include minimum, maximum, sum, mean, standard deviation, standard error of the mean, and variance, were computed for the number of employees, approved amount, turnover prior to application, and amounts required for tools and machinery, business development, and training at sector levels.

\subsubsection{Weighted least squares regression}

The weighted least squares linear regression through the origin was performed to determine the effectsof turnover amount prior to application of additional capital, number of employees, and the amounts required for each distinct specific purpose,namely tools and machinery, business development, and training. Weight estimation was applied based on the rationale of high variability in application amountsacross sectors. Therefore, since the application valuewas the source of heteroscedasticity, linear regression through the origin was done using weighting by application cost.

The stepwise criterion was applied to determine factors that had statistically significant effectson access to additional capital for which the "approved amount" was used as the proxy for access to additional capital. The estimation model was specified as below:

$$
\text { Appr_Amt it }=\tilde{\beta}_{1}\left(\mathrm{TA}_{\text {it }}\right)+\tilde{\beta}_{2}\left(\mathrm{TM}_{\text {it }}\right)+\tilde{\beta}_{3}\left(\mathrm{BD}_{\text {it }}\right)+\tilde{\beta}_{4}\left(\mathrm{TR}_{\text {it }}\right)+\tilde{\beta}_{5}\left(\mathrm{NE}_{\text {it }}\right)+\varepsilon_{\text {it }}
$$

Where: Appr_Amt is the approved amount, TA denotes the turnover amount prior to application, TM represents 
the amount required for tools and machinery, BD symbolises the amount required for business development, TR represents the amount required for training, and NE denotes the number of employees in the firm. While the Appr_Amt is the dependent variable, number of employees, turnover prior to application, and distinct amounts required for tools and machinery, business development, and training were the independent variables in the model. The $\beta$ s represent the estimated coefficients at $95 \%$ confidence interval. The same model was further run at sectoral level to determine the influence of the each covariate on approved amount of additional capital in each distinct sector.

\section{RESULTS AND ANALYSIS}

This section provides results on descriptive statistics and weighted least squares regression analysis performed.

\subsection{Descriptive Statistics}

Results on descriptive statistics presented in this section include minimum and maximum values, the sum, mean, standard deviations, standard error of the mean and variances for number of employees, approved amount, turnover prior to application and amounts required for tools and machinery, business development, and training,for the entire dataset across all sectorsand at sectoral level.

Based on the minimum and maximum statistics in Table 1, the least amount of turnover prior to applicationwas R173 886, while the highest amount was R34 768 700. Between the financial years 2011/12 to 2014/15 period, a total of R336 262687 was approved for all the 826 firms across the sectors for distinct specific purposes. The minimum amount approved was R6 316, while the highest amount was R1 596100 during the period under review. From the sum of R336 262687 additional capital approved, R278 549284 was for tools and machinery, R50 743781 was for business development, and R2 074548 was earmarked for training purposes. Some firms did not make applications for additional capital towards tools and machinery, business development, and training.

From the total 826 firms, one firm obtained approval of the highest capital amount of R6 250000 for tools and machinery, while the highest amounts approved for business development and training for two firms amounted to R945 024 and R165 032 respectively. Based on average statistics, each firm on average obtained R407 097 during the period under review. The average amounts spent by each firm on tools and machinery, business development, and training were R278 549 284, R50 743 781, and R2 074548 respectively. The standard deviations show that the amounts of additional capital approved and the amounts approved for tools and machinery, and business development across firms were highly dispersed from the mean amount. Correspondingly, the variance statistics for approved amounts, as well as all the purposes for which the amounts were approved, exhibit high variability across firms. In relation to employment numbers, one firm had the least number of one employee, while the other firm had the highest number of 508 employees. As shown in Table 2,the highestaverage approved additional capital amounting to R447 244.64 during the financial year periods $2011 / 12$ to $2014 / 15$ was made for firms in the manufacturing sector,followed by an average approved amount of R407 519.48to the services sector. For tools and machinery, the largestaverage amount of R379 249.19 was approved for firms in the manufacturing sector,followed by R336 518.86 for firms in the services sector.

\subsection{Weighted least squares regression}

\subsubsection{Both (Services and Manufacturing) sectors}

Based on model 4, theAdjusted R-Square results in Table 3, 70.1\% overall variation in the approved amount was accounted for by turnover prior to application, number of employees, and the amount required for tools and machinery, and business development. The Durbin Watson statistic $(\mathrm{DW}=2.016)$ indicates an absence of autocorrelation in the model.

Model 4 results in Table 4indicate that turnover prior to application and the distinct amounts required for tools and machinery, business development, and training purposes all had statistically significant positive effects on the amounts approved for firms during the financial years period 2011/12 to 2014/15. The $t$-statistics and corresponding estimated coefficients show that the amount required for tools and machinery had the highest significant positive effect on the amount approved,followed by turnover prior to application. The amount required for business development demonstrated a significant positive effect on the approved amount while the number of employees had the least significant but positive effect on the approved amount.

Based on estimated coefficients, for every $1 \%$ rise in the amount required to be spent on tools and machinery, about $0.48 \%$ additional capital was approved towards the total approved amount. Similarly, for every $1 \%$ increase in turnover prior to application, nearly $0.33 \%$ of the total amount applied for was approved. Moreover, a $1 \%$ rise in the amount required for business development leads to about $0.18 \%$ increase in the total amount approved, while for every $1 \%$ increase in the number of employees in firms, there was a corresponding increase of about $0.09 \%$ in the total amount approved during 2011/12 to 2014/15 financial years period. 


\subsection{Sector level analysis}

The weighted least squares regression through the origin was conducted for sectors with firms whose sample sizes were considered large for inferential purposes based on the best statistical principles and practices. Based on the standard statistical principles, a sample size less than 30 is considered small. In this study, only the services sector $(n=714)$ and manufacturing sector $(n=85)$ had large sample sizes.

\subsubsection{Services Sector}

Model 3 Adjusted R-Square results in Table 5 show that about $68 \%$ overall variation in the approved amount was accounted for by turnover prior to application, number of employees, and the amount required for tools and machinery, and business development. The Durbin Watson statistic $(\mathrm{DW}=1.997)$ designatesan absence of autocorrelation in the model.

The $t$-statistics in Table 6indicate that the amount required for tools and machinery had the uppermost significant positive influenceon the amount approved,followed by turnover prior to application. The amount required for business development demonstrated the least significant but positive effect on the approved amount. The corresponding estimated coefficients show that for every $1 \%$ upsurge in the amount required for spending on tools and machinery, about $0.48 \%$ additional capital was approved towards the total approved amount. Congruently, for every $1 \%$ rise in turnover prior to application, nearly $0.36 \%$ of the total amount applied for was approved. Finally, a $1 \%$ rise in the amount required for business development led to approximately $0.20 \%$ increase in the total amount approved for firms in the services sectorduring the period under review.

\subsubsection{Manufacturing Sector}

Based on model 3, the Adjusted R-Square results in Table 7, approximately $81.7 \%$ overall variation in the approved amount was accounted for by turnover prior to application, and the amount required for tools and machinery, and business development. The Durbin Watson statistic $(\mathrm{DW}=2.065)$ exhibits absence of autocorrelation in the model. Table 8 model $3 t$-statistics results show that the turnover prior to application amount had the highest significant positive effect on the amount approved,followed by the amounts required for tools and machinery,and lastly business development. The coefficients show that for every $1 \%$ increase in turnover prior to application, about $0.49 \%$ of the total amount applied for was approved.Correspondingly, every $1 \%$ rise in the amount required to be spent on tools and machinery led to approximately $0.44 \%$ increase in the total approved amount. Lastly, a $1 \%$ rise in the amount required for purposes of business development led to about $0.12 \%$ increase in the total amount approved during the period 2011/12 to 2014/15.

\subsection{Conclusion}

\section{CONCLUSION AND RECOMMENDATIONS}

The objective of this study was to examine selected business factors determining access to BBSDP funding over the financial period 2011/12 to 2014/15. With particular focus on SMEs in the services sector and manufacturing sector, the estimated results indicate that turnover prior to application and the different amounts required for tools and machinery, business development, and training purposes, all had statistically significant positive effects on the amounts approved for SMEs during the financial periods 2011/12 to 2014/15. The estimated coefficients indicate that for every $1 \%$ increase in the amount required to be spent on tools and machinery, about $0.48 \%$ additional capital was approved towards the total approved amount. Correspondingly, for every $1 \%$ increase in turnover prior to application, nearly $0.33 \%$ of the total amount applied for was approved. Moreover, a $1 \%$ rise in the amount required for business development leads to about $0.18 \%$ increase in the total amount approved, while for every $1 \%$ increase in the number of employees in firms, there was a corresponding rise of about $0.08 \%$ in the total amount approved during the period 2011/12 to 2014/15.

\section{$5.2 \quad$ Recommendations}

Given thefindings that turnover prior to application and the distinct amounts required for tools and machinery, business development, and training purposes had statistically significant positive effects on amounts approved for SMEs, it is important that SMEs in the services and manufacturing sectors invest more in tools and machinery. At the same time,they need to ensure increased turnover in order to sustain high levels of profitability requiredto grow business. Therefore, government should also design and implement programmes aimed at continuously imparting skills and knowledge customised to enable SMEs to conduct planning, review of their financial analysis, and forecasting of funding thresholds necessary to sustain their businesses in the face of different dynamic business conditions. 


\section{REFERENCES}

[1] Abdulsaleh, A.M.,\&Worthington, A.C. 2013. Small and medium-sized enterprises financing: A review of literature. International Journal of Business and Management, 8(14):36-54.

[2] Abor, J. 2007. Industry classification and the capital structure of Ghanaian SMEs. Studies in Economics and Finance, 24(3):207-219.

[3] Ahiawodzi, A.K.,\&Adade, T.C. 2012. Access to credit and growth of small and medium scale enterprises in the Ho Municipality of Ghana. British Journal of Economics, Finance and Management Sciences, 6(2):34-51.

[4] Akorsu, P.K.,\&Agyapong, D. 2012. Alternative model for financing SMEs in Ghana. International Journal of Arts and Commerce, 1(5):136-148.

[5] Department of Small Business Development 2010. Black Business Supplier Development Programme. Republic of South Africa.

[6] Falkena, H., Abedian, I., Blottnitz, M., Coovadia, C., Davel, G., Madungandaba, J., Masilela, E., \&Rees, S. 2013. SMEs' access to finance in South Africa - A supply side regulatory review.

[7] Ferreira, E., Strydom, J., \& Nieuwenhuizen, C. 2010. The process of business assistance to small and medium enterprises in South Africa: preliminary findings. Journal of Contemporary Management, 7, 94109.

[8] Kumah, O.M.,\&Omilola, B. 2014. Small business is big business: A UNDP perspective on SMME Development in South Africa. UNDP South Africa.

[9] Le, P.N.M. 2012. What Determines the Access to Credit by SMEs? A Case Study in Vietnam. Journal of Management Research, 4(4): 90-115.

[10] Mago, S., \& Toro, B. 2013. South African government's support to small, medium micro-enterprise (SMMEs): The case of King William's Town area.J Economics, 4(1): 19-28.

[11] Michaelas, N., Chittenden, F.,\& Poutziouris, P. 1999. Financial policy and capital structure choice in U.K. SMEs: Empirical evidence from company panel data. Small Business Economics, 12(2):113-130.

[12] National Credit Regulator. 2011. Literature review on small and medium enterprises' access to credit and support in South Africa. Underhill Corporate Solutions.

[13] Statistics South Africa. 2016. Economy. Republic of South Africa. Accessedfrom:http://www.statssa.gov.za/?page_id $=1854 \& P P N=P 0441 \& S C H=6637$

[14] Xiang, D., \& Worthington, A.C. 2013. The impact of government financial assistance on SMEs in Australia during the GFC (No. finance: 201307). Available from:https://www120.secure.griffith.edu.au/research/file/27bd2613-072a-42dc-8f79-

3259156ddcd0/1/2013-07-the-impact-of-government-financial-assistance-on-SMEs-in-Australia-duringthe-GFC.pdf[Accessed:2015, July 14].

Table 1: Descriptivestatistics

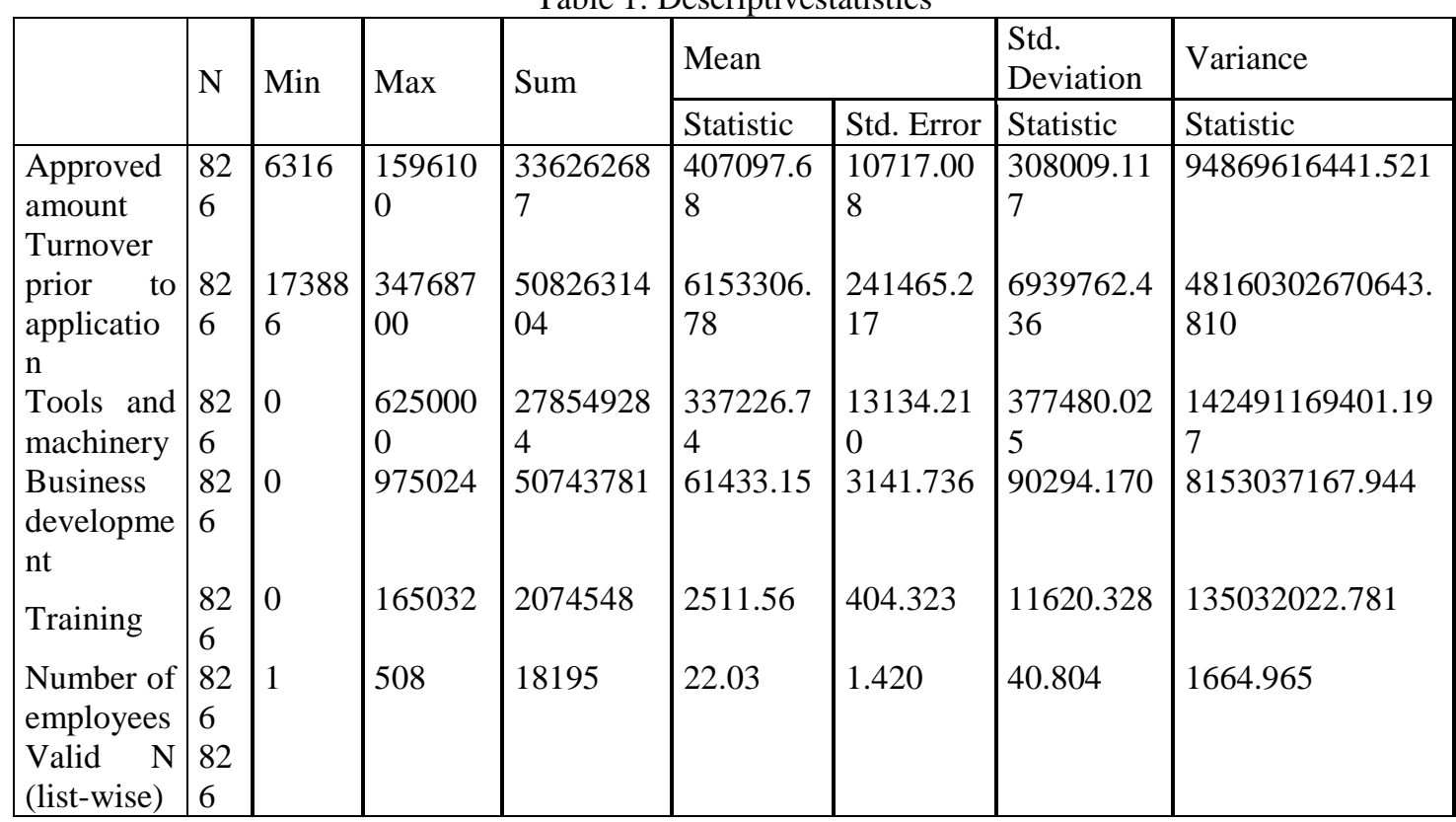


Table 2 : Descriptive statistics

\begin{tabular}{|c|c|c|c|c|}
\hline Sector & Variable & Mean & $\begin{array}{l}\text { Std. } \\
\text { Deviation }\end{array}$ & $\mathrm{N}$ \\
\hline Services & $\begin{array}{l}\text { Approved amount } \\
\text { Application cost } \\
\text { Turnover prior to application } \\
\text { Tools and machinery } \\
\text { Business development } \\
\text { Training } \\
\text { Number of employees }\end{array}$ & \begin{tabular}{|l|}
407519.48 \\
789617.57 \\
6049889.27 \\
336518.86 \\
62828.27 \\
2682.61 \\
21.96
\end{tabular} & $\begin{array}{l}309050.304 \\
1364641.945 \\
6823784.746 \\
387398.782 \\
93585.177 \\
12315.290 \\
41.177\end{array}$ & 714 \\
\hline Manufacturing & $\begin{array}{l}\text { Approved amount } \\
\text { Application cost } \\
\text { Turnover prior to application } \\
\text { Tools and machinery } \\
\text { Business development } \\
\text { Training } \\
\text { Number of employees }\end{array}$ & \begin{tabular}{|l|}
447244.64 \\
839829.51 \\
7051261.87 \\
379249.19 \\
54529.61 \\
1872.51 \\
24.79 \\
\end{tabular} & $\begin{array}{l}326522.494 \\
681980.771 \\
7579502.290 \\
337404.015 \\
68811.610 \\
6013.260 \\
43.200 \\
\end{array}$ & 85 \\
\hline
\end{tabular}

Table 3: Model summary ${ }^{\text {b,c, d }}$

$\begin{array}{llllll}\text { Model } & \text { R } & \text { R Square } & \begin{array}{l}\text { Adjusted R } \\ \text { Square }\end{array} & \begin{array}{l}\text { Std. Error of the } \\ \text { Estimate }\end{array} & \begin{array}{l}\text { Durbin- } \\ \text { Watson }\end{array} \\ 1 & .723 & .522 & .522 & 437505282.667 & \\ 2 & .819 & .671 & .670 & 363236298.629 & \\ 3 & .835 & .698 & .697 & 348198376.426 & 2.016 \\ 4 & .838^{\mathrm{a}} & .703 & .701 & 345667953.553 & \end{array}$

a. Predictors: Tools and machinery, Turnover prior to application, Business development, No. of employees

b. Dependent Variable: Approved amount

c. Linear Regression through the Origin

d. Weighted Least Squares Regression - Weighted by Application amount

Table 4 : Coefficients ${ }^{\mathrm{a}, \mathrm{b}, \mathrm{c}}$

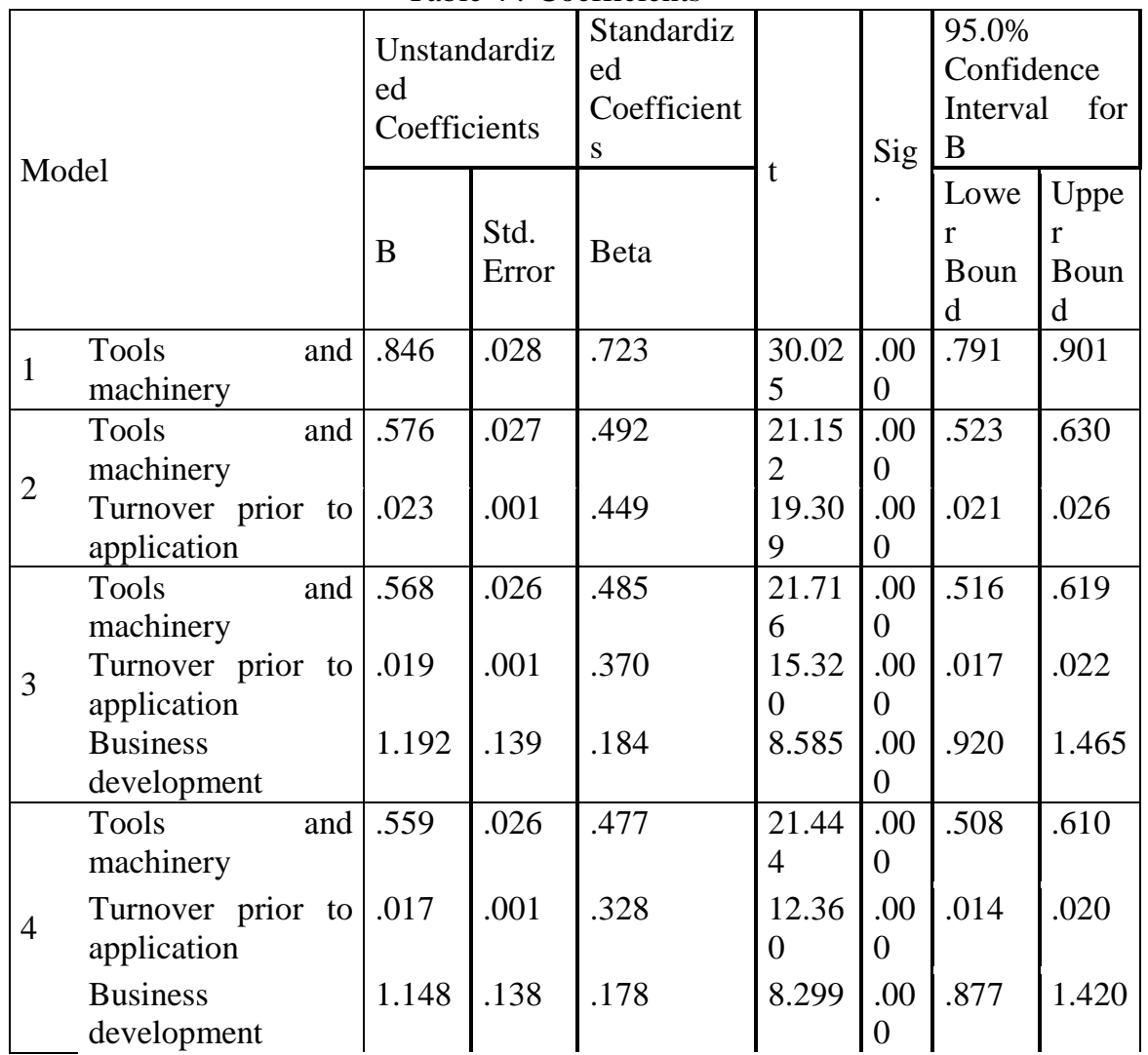




\begin{tabular}{ll|l|l|l|l|l|l|l|}
\hline $\begin{array}{l}\text { Number } \\
\text { employees }\end{array} \quad$ of & $\begin{array}{l}1228 . \\
7\end{array}$ & $\begin{array}{l}339.5 \\
6\end{array}$ & .085 & 3.618 & $\begin{array}{l}.00 \\
0\end{array}$ & $\begin{array}{l}562.2 \\
0\end{array}$ & $\begin{array}{l}1895 . \\
2\end{array}$ \\
\hline
\end{tabular}

a. Dependent Variable: Approved amount

b. Linear Regression through the Origin

c. Weighted Least Squares Regression - Weighted by Application cost

Table 5 : Model Summary ${ }^{\mathrm{b}, \mathrm{c}, \mathrm{d}, \mathrm{e}}$

\begin{tabular}{|c|c|c|c|c|c|c|c|}
\hline \multirow[b]{2}{*}{$\begin{array}{l}\text { Mod } \\
\text { el }\end{array}$} & \multicolumn{2}{|l|}{$\mathrm{R}$} & \multirow[b]{2}{*}{$\begin{array}{l}\mathrm{R} \\
\text { Squar } \\
\mathrm{e}\end{array}$} & \multirow[b]{2}{*}{$\begin{array}{l}\text { Adjust } \\
\text { ed R } \\
\text { Square }\end{array}$} & \multirow[b]{2}{*}{$\begin{array}{l}\text { Std. Error } \\
\text { of the } \\
\text { Estimate }\end{array}$} & \multicolumn{2}{|c|}{$\begin{array}{l}\text { Durbin-Watson } \\
\text { Statistic }\end{array}$} \\
\hline & $\begin{array}{l}\text { Sector = } \\
\text { Services } \\
\text { (Selecte } \\
\text { d) }\end{array}$ & $\begin{array}{l}\text { Sector } \sim= \\
\text { Services } \\
\text { (Unselect } \\
\text { ed) }\end{array}$ & & & & $\begin{array}{l}\text { Sector } \\
= \\
\text { Service } \\
\text { S } \\
\text { (Selecte } \\
\text { d) }\end{array}$ & $\begin{array}{l}\text { Sector } \sim= \\
\text { Services } \\
\text { (Unselect } \\
\text { ed) }\end{array}$ \\
\hline 3 & $\begin{array}{l}.708 \\
.807 \\
.826^{\mathrm{a}}\end{array}$ & 1.000 & $\begin{array}{l}.501 \\
.651 \\
.682\end{array}$ & $\begin{array}{l}.500 \\
.650 \\
.680\end{array}$ & $\begin{array}{l}446430367 \\
.43 \\
373607873 \\
.75 \\
356900734 \\
.51\end{array}$ & 1.997 & 1.883 \\
\hline
\end{tabular}

a. Predictors: Tools and machinery, Turnover prior to application, Business development

b. Unless noted otherwise, statistics are based only on cases for which Sector = Services

c. Dependent Variable: Approved amount

d. Linear Regression through the Origin

e. Weighted Least Squares Regression - Weighted by Application cost

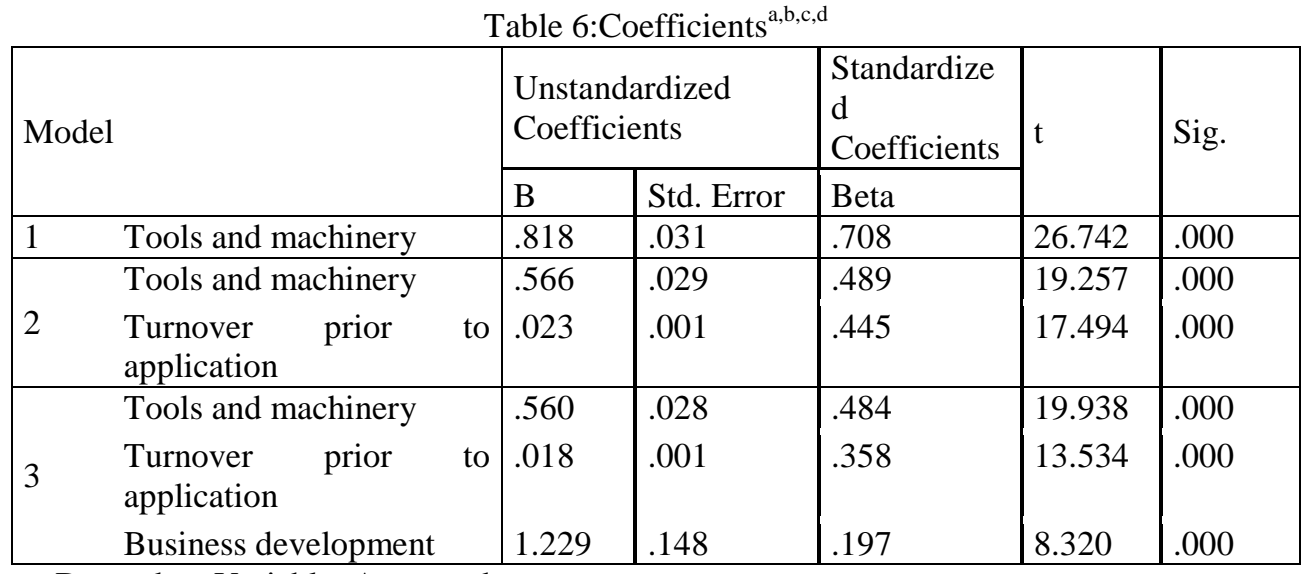

a. Dependent Variable: Approved amount

b. Linear Regression through the Origin

c. Weighted Least Squares Regression - Weighted by Application cost

d. Selecting only cases for which Sector $=$ Services

Table 7: Model Summary ${ }^{\mathrm{b}, \mathrm{c}, \mathrm{d}, \mathrm{e}}$

\begin{tabular}{|c|c|c|c|c|c|c|c|}
\hline \multirow[b]{2}{*}{$\begin{array}{l}\text { Mo } \\
\text { del }\end{array}$} & \multicolumn{2}{|l|}{$\mathrm{R}$} & \multirow[b]{2}{*}{$\begin{array}{l}\text { R } \\
\text { Squa } \\
\text { re }\end{array}$} & \multirow[b]{2}{*}{$\begin{array}{l}\text { Adjust } \\
\text { ed R } \\
\text { Squar } \\
\text { e }\end{array}$} & \multirow[b]{2}{*}{$\begin{array}{l}\text { Std. Error } \\
\text { of the } \\
\text { Estimate }\end{array}$} & \multicolumn{2}{|c|}{$\begin{array}{l}\text { Durbin-Watson } \\
\text { Statistic }\end{array}$} \\
\hline & $\begin{array}{l}\text { Sector = } \\
\text { Manufact } \\
\text { uring } \\
\text { (Selected) }\end{array}$ & $\begin{array}{l}\text { Sector = } \\
\text { Manufact } \\
\text { uring } \\
\text { (Unselect } \\
\text { ed) }\end{array}$ & & & & $\begin{array}{l}\text { Sector = } \\
\text { Manufact } \\
\text { uring } \\
\text { (Selected) }\end{array}$ & $\begin{array}{l}\text { Sector = } \\
\text { Manufact } \\
\text { uring } \\
\text { (Unselect } \\
\text { ed) }\end{array}$ \\
\hline 1 & $.833^{\mathrm{a}}$ & & .694 & .691 & $\begin{array}{l}39834866 \\
2.41\end{array}$ & 2.065 & 2.086 \\
\hline
\end{tabular}




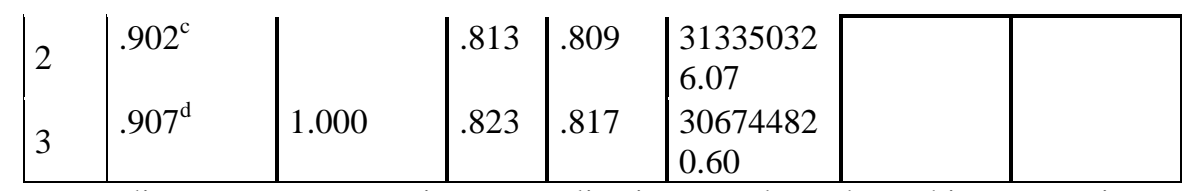

a. Predictors: Turnover prior to application, Tools and machinery, Business development

b. Unless noted otherwise, statistics are based only on cases for which Sector = Manufacturing

c. Dependent Variable: Approved amount

d. Linear Regression through the Origin

e. Weighted Least Squares Regression - Weighted by Application cost

Table 8 : Coefficients ${ }^{\mathrm{a}, \mathrm{b}, \mathrm{c}, \mathrm{d}}$

\begin{tabular}{|c|c|c|c|c|c|c|}
\hline \multicolumn{2}{|c|}{ Model } & \multicolumn{2}{|c|}{$\begin{array}{l}\text { Unstandardized } \\
\text { Coefficients }\end{array}$} & \multirow{2}{*}{$\begin{array}{l}\text { Standardized } \\
\text { Coefficients } \\
\text { Beta }\end{array}$} & \multirow[t]{2}{*}{$\mathrm{t}$} & \multirow[t]{2}{*}{ Sig. } \\
\hline & & $\mathrm{B}$ & Std. Error & & & \\
\hline 1 & $\begin{array}{l}\text { Turnover prior to } \\
\text { application }\end{array}$ & .049 & .004 & .833 & 13.811 & .000 \\
\hline \multirow[t]{2}{*}{2} & $\begin{array}{l}\text { Turnover prior to } \\
\text { application }\end{array}$ & .030 & .004 & .514 & 7.952 & .000 \\
\hline & Tools and machinery & .601 & .083 & .470 & 7.263 & .000 \\
\hline \multirow{3}{*}{3} & $\begin{array}{l}\text { Turnover prior to } \\
\text { application }\end{array}$ & .029 & .004 & .492 & 7.682 & .000 \\
\hline & Tools and machinery & .557 & .084 & .435 & 6.663 & .000 \\
\hline & Business development & 1.077 & .501 & .112 & 2.148 & .035 \\
\hline
\end{tabular}

a. Dependent Variable: Approved amount

b. Linear Regression through the Origin

c. Weighted Least Squares Regression - Weighted by Application cost

d. Selecting only cases for which Sector $=$ Manufacturing 